\title{
Governing Board Attributes as Profitability Influencers under Endogeneity: An Econometric Analysis in South Africa
}

\author{
Navitha Singh Sewpersadh* \\ University of KwaZulu-Natal
}

\section{ARTICLE INFO}

Article history:

Received 28 July 2019

Revised 15 October 2019 \& 12

November 2019

Accepted 25 November 2019

Published 7 January 2020

\section{Keywords:}

Board interlocks

ROA

Corporate governance

IV

GMM

JSE

Managerial opportunism

Profitability

\begin{abstract}
Presently, the oversight role performed by the governing board has been interrogated due to the demise of several corporate giants. The governing board is responsible for advancing the strategic direction of the company by ensuring superior performance whilst managing risks. Accordingly, this study investigated whether the governing board has any influence on a firm's profitability by using OLS and GMM estimation on an unbalanced panel of 130 firms over a six-year period. ROA served as a proxy for firm performance and several board-level governance variables were selected namely board size, board independence, CEO duality, director qualifications, and board interlocks. From an econometric contribution, this study found that the addition of instrument variables in the GMM estimation model has proven to be robust in examining corporate governance variables. GMM is also robust in controlling endogeneity and a possible bi-directional causality between board and profitability. From a theoretical contribution, agency, resource dependence and management hegemony theories are highly prevalent in the governing boards of the JSE. The results of this study are as envisaged in the SCP paradigm. All hypotheses were supported, showing overall that profitability is significantly influenced by the board attributes. This study provides a useful analysis of the theoretical framework used by academic writers as a foundation for model specification as well as contributes to the econometric methodology of corporate governance. These findings will also advise future researchers, stakeholders and regulators in better understanding the role of board composition from a profit maximisation and sustainability outlook.
\end{abstract}

\section{Introduction}

The recent news of the technical recession in South Africa (SA) has brought about the speculation of an impending financial crisis especially given the lack of investor confidence in the market (Head, 2018). Furthermore, from the year 2000, the unemployment rate in SA averaged 25.57 percent but escalated to 27.2 percent in 2018 (Moya, 2018). To avoid market stagnation, firms through their governing boards need to adapt to the fluctuating market conditions and pursue growth orientated strategies in order to maximise shareholders returns and for their long-term survival. The board must also strictly monitor management to reduce management inefficiency (Petchsakulwong \& Jansakul, 2018) and control managerial opportunistic behaviour (Jensen, 1986). Managerial opportunism is a situation where the top executives rank their self-interests over the interests of the firm's investors (Jensen, 1986). In a world of change, leadership needs to act with agility to ensure a firm's survival. Agility is the ability to move faster than change and respond flexibly to change in a stable informed manner. In this context, the governing board must act with agility whilst playing the pivotal oversight role in protecting stakeholder interests. A comparative analysis of the failures of Enron, WorldCom and HealthSouth, Parmalat, Royal Ahold, and Vivendi Universal revealed that the companies had ineffective boards and corporate governance practices (Soltani, 2014). Similarly, the inadequate oversight role of the

\footnotetext{
* Corresponding author.

E-Mail address: sewpersadh@ukzn.ac.za

ORCID: 0000-0002-3219-7974
} 
governing bodies led to Toshiba's overstatement of profits in the financial statements to attain profit targets (Melé, Rosanas, \& Fontrodo, 2017).

The negligence of the essential oversight role that boards play illustrates the need for continued emphasis and reinforcement of governance practices worldwide. In order for the company to grow and succeed, the governing board requires exposure, experience and education. The contribution of this study has, firstly, established which econometric method is superior when dealing with corporate governance and, secondly, identified the board attributes that act as profitability influencers. Prior research ignored the endogeneity issue by using traditional ordinary least squares (OLS) or fixed-effects methods that can have severe consequences for inference (Shao, 2019). Specifically, the limitation in the governance literature is due to endogeneity issues stemming from unobservable heterogeneity, simultaneity and dynamic endogeneity (Wintoki, Linck, \& Netter, 2012). Prior literature such as Wintoki et al. (2012) and Shao (2018) has been sufficiently generalised in developed markets and large economies like China. However, this study responds to the endogeneity concerns in SA, which has a well-developed corporate governance structure but an ailing economic environment. In SA, listed companies have stringent listing requirements as regulated by the JSE, and the non-adherence thereof results in varying consequences such as the issuance of a public notice, suspension or delisting.. For that reason, JSE listed companies have been selected for this study since it would result in more robust and fruitful contributions to the literature.

This study is also motivated by recent literature on corporate governance and corporate performance (Zabri, Ahmad, \& Wah, 2016; Habib, 2016; Scafarto, Ricci, Corte, \& De Luca, 2017; Bhabra \& Eissa, 2017; Paniagua, Rivelles, \& Sapena, 2018; Shao, 2019). However, this study extends the range of investigations from the recent literature but differs in scope by performing a comprehensive analysis and understanding of board as a profitability influencer using board size, board independence, and CEO duality, with the additional variables of board interlocks and board skills as proxies for the board structure. The remainder of this paper is structured as follow: literature review, research method, this study's results as well as the conclusion and recommendations of the study.

\section{Literature Review}

\section{Corporate Governance Structure in SA}

The oversight role played by the governing board is regulated by each country's code of corporate governance. In SA, the code of corporate governance that all organisations must adhere to is the King report which was first promulgated in 1994 (King I) then subsequently replaced by the enhancements of King II followed by King III. The King III report has a stakeholder-inclusive approach. The stakeholder enabling principle implies that all directors have a fiduciary duty to ensure that the organisation is managed in the interests of its stakeholders (Freeman, 1984; King Committee, 2016). A fiduciary duty is to act with integrity and in good faith for the welfare of the company (King Committee, 2009). King III imposes four underpinning good governance values on the governing board as stipulated below in Table 1:

Table 1. Four underpinning good governance values

\begin{tabular}{|c|c|c|c|}
\hline Responsibility & Accountability & Fairness & Transparency \\
\hline $\begin{array}{l}\text { The board is responsible for } \\
\text { governance and takes } \\
\text { remedial actions to keep the } \\
\text { firm on its strategic path. }\end{array}$ & $\begin{array}{l}\text { The board should be able } \\
\text { to defend its choices and } \\
\text { actions to all } \\
\text { stakeholders. }\end{array}$ & $\begin{array}{l}\text { The board's decisions and } \\
\text { actions should ensure that fair } \\
\text { thought is given to the } \\
\text { interests of all the company's } \\
\text { stakeholders. }\end{array}$ & $\begin{array}{l}\text { The board should divulge } \\
\text { information that allows } \\
\text { stakeholders to make an } \\
\text { informed analysis of the } \\
\text { entity's performance. }\end{array}$ \\
\hline
\end{tabular}

Source: King Committee (2009)

The governing boards therefore have to balance the interests of various stakeholder groups and resolve potential conflicts, as well as balance the objective of profit maximisation with long-term survival and value creation (Cornforth, 2001). For this reason, Jensen (2001) criticised the stakeholder theory for undermining the principles of value-seeking behaviour by directing managers to serve "many masters" resulting in "managerial confusion", inefficiency, conflict and potential competitive failure (Jensen, 2001). 
Necessitated by the growing financial instability, namely, the financial crises in the United States of America, the sovereign fund crisis in the European Union and Brexit, the King IV Report was released on 1 November 2016 with an effective date of 1 April 2017 (King Committee, 2016). King IV defines corporate governance as an exercise of ethical and effective leadership by the governing body towards the achievement of governance outcomes, namely, ethical culture, good performance, effective control and legitimacy (King Committee, 2016). The King Committee (2016) defines corporate governance (depicted pictorially in Figure 1) as an exercise of ethical and effective leadership.
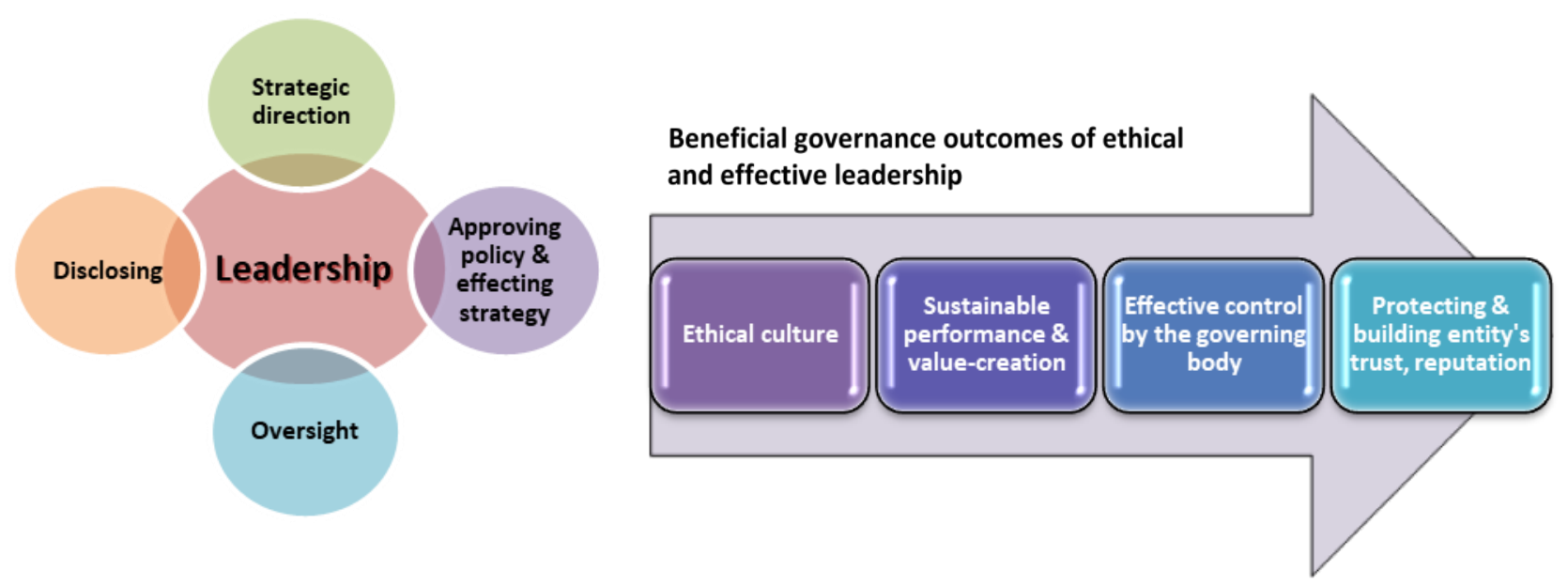

Figure 1. Leadership constructs

Source: extracted from the King Committee (2016) and depicted by the author

The principles outlaid in King III are carried over to the King IV report which has simplified the code of corporate governance into 17 principles for entities to adopt in their governance structures. The following principles and recommended practices have been extracted from the King IV report specifically for this study's variables as presented in Table 2.

Table 2. Extracted principles for study variables

\section{Principle}

4 The governing body should appreciate that the organisation's core purpose, its risks and opportunities, strategy, business model, performance and sustainable development are all inseparable elements of the value creation process.

\section{Recommended Practice (RP)}

RP3: The organisations short-, medium- and long-term strategy as formulated and developed by management should be approved by the governing body. When considering the proposed strategy for approval, the governing body should challenge it constructively with reference to, among others, the following:

RP3(c): The extent to which the proposed strategy depends on the resources and relationships connected to the various forms of capital (firm size).

RP3(e): The increase, decrease or transformation of the various forms of capital that may result from the execution of the proposed strategy (leverage).

RP6: The governing body should exercise ongoing oversight of the implementation of strategy and operational plans by management against agreed performance measures and targets (ROA, firm growth). 
7 The governing body should comprise the appropriate balance of knowledge, skills, experience, diversity, and independence for it to discharge its governance role and responsibilities objectively and efficiently.
RP6: The board should assume responsibility for its composition by setting the direction and approving the processes for it to attain a balance of knowledge, skills, experience and diversity (Directors qualifications).

RP7(c): When determining the requisite number of members of the board, the need for a sufficient number of members that qualify to serve on board committees should be considered (Board size).

RP8: The board should consist of a majority of non-executive directors of whom the majority should be independent (Board independence).

RP18: A candidate for election as a non-executive director of the board should be requested to provide the governing body with details of professional commitments and a statement that confirms that the candidate has sufficient time available to fulfil the responsibilities as director (Board interlocks).

RP31: The Chairperson of the board should be an independent nonexecutive director (CEO duality).

Source: extracted from the King Committee (2016) and depicted by the author

\section{Structure-conduct-performance (SCP) paradigm}

The traditional SCP paradigm is theorised that superior market concentration leads to a lower degree of competition resulting in higher profits earned due to collusive or monopolistic reasons (Molyneux \& Forbes, 1995). Li and Yu (2016) explained that the market structure directly influences market conduct, which in turn directly affects the market performance with a feedback effect of market performance on market conduct and structure as depicted in Figure 2.

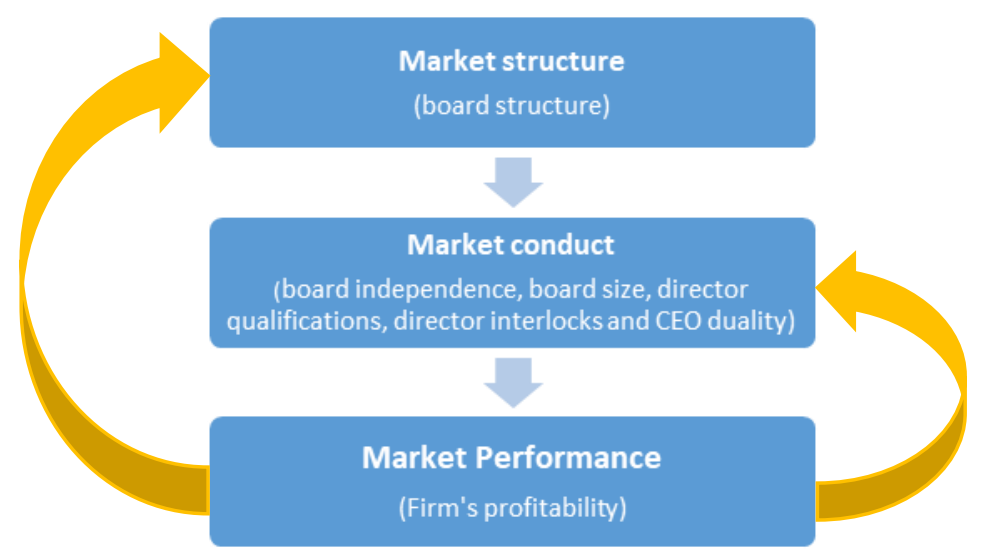

Figure 2. SCP paradigm by Molyneux and Forbes (1995) as applied in this study

\section{Source: Author}

In this paper, as depicted in Figure 2, the SCP paradigm is applied to the model where the structure refers to the board structure; the conduct corresponds to the board's independence, the board size, director qualifications, board interlocks and CEO duality; and the performance indicates the firm's profitability. Additionally, Molyneux and Forbes (1995) also propose the efficiency hypothesis where efficiency dictates the relationship between market structure and the firm. In this context, if a firm has a higher degree of efficiency, for instance, a low-cost structure in comparison to its competitors, it can strategise by maximising profits by maintaining the current prices and firm size; or it can maximise profits by reducing prices and expanding firm size (Molyneux \& Forbes, 1995). 
Empirical literature and hypothesis development

\section{CEO Duality}

The extant theoretical literature on corporate governance shows ambivalence towards the concept of CEO duality. The agency theory highlights the agency conflicts of management acting for their own benefit rather than for that of the owner (Berle \& Means, 1932). Managerial opportunism occurs due to the separation of ownership/finance (principal) and control/management of the company (agent) (Jensen \& Meckling, 1976). To deter the practice of managerial opportunism, the agency theory suggests that there should be a separation of the role of CEO from the chairperson of the board's duties, since the presence of CEO duality compromises the board's monitoring function ultimately leading to poor firm performance (Donaldson \& Davis, 1991). The presence of dual roles leads to a concept known as a CEO-dominated board, where the CEO and other senior managers exercise the main power and the board serving a symbolic role (Cornforth, 2001). Supporting this contention, management hegemony proposes that the CEO would be in a better position for strategic decision-making as opposed to the board who are viewed as ceremonial rubber-stampers (Hung, 1998; Cornforth, 2001). On the other hand, the stewardship theory believes that the CEO and the board work altruistically towards a common goal where managerial achievement and sense of responsibility benefits a firm (Donaldson \& Davis, 1991), with the result that CEO duality would promote, rather than hinder, firm performance (Boyd, 1995).

The findings of the empirical literature relating to the relationship between CEO duality and profitability are inconsistent. In the study by Habib (2016), the findings showed that CEO duality improves the firm's performance and is thus positively correlated with ROA. However, Ciftci et al. (2019) failed to find any significant relationship between CEO duality and ROA. Conversely, in the study by Kalsie and Mittal Shrivastav (2016) and Qadorah and Fadzil (2018), it was found that the governance of a board is significantly compromised in the presence of CEO duality in a company. Furthermore, Sewpersadh (2019) found that the presence of CEO duality increases the degree of leverage due to managements preference for debt. However, with increases in the debt financing, there are also increases in the financial risk of a firm (Sewpersadh, 2019). For this study, the hypothesis is derived from the earliest corporate governance theory, agency theory and the King III report as follows:

\section{H1: CEO duality is negatively correlated with profitability}

\section{Board interlocks}

The resource dependence model established that firms do not have the internal capacity to produce and perform their functions effectively without making relations and transacting with their external environment to attain the requisite resources and services in order to sustain themselves (Aldrich \& Pfeffer, 1976; Pfeffer, 1972). This theory links to the co-optation theory that posits a firm co-opts members of influential outside firms so that they work to further the interests of the firms that co-opted them (Pfeffer \& Salancik, 1978); thus giving rise to board interlocks which is when an executive director at one firm joins the board of another firm (Pfeffer \& Salancik, 1978). Interlocking directorates are a mechanism to manage environmental insecurity, to acquire access to an assortment of skills and resources, to enable communication across firms, and to provide legitimacy for the focal firm (Pfeffer, 1987). Essentially, this theory recognises that the value of directors lies in using their expertise in advising management and their fellow directors on the board to make concerted efforts for the welfare of the organisation.

Several limitations have been highlighted in the extant literature regarding board interlocks. According to Greenwood (2004), in the event of board interlocks, CEOs serving on each other's boards are unlikely to rigorously criticise their peers and even if they are so inclined, the lack of time and access to information prevents the directors from a serious review of company managers. Ultimately, the degree of internal cohesion within the board is reduced since directors serving on numerous boards would limit their time and attention given to each board they serve. MansKemp et al. (2016) recommended that directors should limit their board memberships to give sufficient attention to the activities of all firms, which they serve. For this study, boards that have directors with a high networking ability will have a negative association with profitability due to work constraints and scheduling conflicts. This study hypothesises that:

\section{H2: Board interlocks is negatively correlated with profitability}




\section{Board size}

The resource dependence model posits that an essential element in improving the effectiveness of management in a firm is the number of directors serving on the board (Dalton et al., 1999). For that reason, larger boards will improve firm performance, implying that there is a positive relationship between board size and firm performance (Dalton et al., 1999). Accordingly, the greater the firm's need for co-optation, the larger the size of the board (Pfeffer, 1972) since boards that have a large number of external connections will benefit from rapid access to critical resources and external information (Kor \& Sundaramurthy, 2009). In addition to these networking opportunities and access to business resources, larger boards could also benefit the company through advice and counsel and facilitating diversity on the board in terms of members with experience, skill sets, gender and race (Dalton \& Dalton, 2005). Contrarily, large boards also have the risks of being ineffective due to the difficulty in coordinating their activities (Jensen, 1993). There have been divergent findings in the extant literature. Zabri et al. (2016) and Habib (2016) found that board size had a negative relationship with ROA as well as Paniagua et al. (2018) that found higher numbers of board members implies a lower ROE. The study by Scafarto et al. (2017), Qadorah and Fadzil (2018) and Ciftci et al. (2019) found that there was a positive correlation between board size and ROA. Furthermore, Sewpersadh (2019) established that the size of the governing board plays a decisive oversight role of monitoring management. In terms of the resource dependence model, firms that have a large number of directors on board may be efficient and can serve better; and thus have a positive association with profitability (Sewpersadh, 2019). Hence, this study hypotheses that:

\section{H3: Board size is positively correlated with profitability}

\section{Board independence}

Agency theory postulated that the governing board would monitor management's behaviour to protect shareholders' interests (Fama \& Jensen, 1983; Jensen \& Meckling, 1976) and provide expertise. For this reason, an insiderdominated board may be ineffective in their value contribution and may also abuse their power for their own benefit (Dalton \& Daily, 1999). The stewardship theory postulated that the governing board safeguards shareholder returns by the independent directors jointly working with management in developing strategies and monitoring performance (Davis, Schoorman, \& Donaldson, 1997; Donaldson \& Davis, 1991). On the contrary, management hegemony theory supports that management are the strategic decision-makers since the board members do not have the ability or the aptitude to drive profitability in a company (Hung, 1998; Cornforth, 2001). The empirical study by Bhabra and Eissa (2017) found that board independence is positively associated with the occurrence of a financial distress event thus negatively associated with profitability, whereas the study by Ciftci et al. (2019) found a negative correlation between board independence and profitability. The value contribution from independent directors is questionable under the management hegemony theory due to information asymmetry, lack of strategic market knowledge and time. For this reason, this study assumes a negative relationship between board independence and firm performance. This leads to the following hypothesis:

\section{H4: Board independence is negatively correlated with profitability}

\section{Director Qualifications}

In SA, the King report as well as the Protection of Investment Act 22 of 2015 recommended that directors should act honourably and in good faith, with reasonable skill, diligence and care (King Committee, 2016; Parliament of the Republic of South Africa, 2015). Specifically, in King IV with reference to Table 2, it is outlined in recommended practice six that directors must possess the required skill to effectively perform their monitoring role on the board. However, Bhabra and Eissa, (2017) stated that boards with directors where the number of educational achievements varies significantly can lead to greater difficulties in reaching consensus on strategic corporate policies. Furthermore, the varied opinions of these directors could result in lengthy delays in arriving at a strategic decision, which could prove to be costly in the long-term, especially for firms experiencing a decline in performance (Bhabra \& Eissa, 2017). Due to the criticism of directors being enticed by reappointments to the board leading to them being agreeable to management in the management hegemony theory as well as information asymmetry (Hung, 1998) and aligned to the study by Bhabra and Eissa (2017), this study assumes that boards with a majority (>80\%) of the directors having 
postgraduate degrees have a negative association with profitability due to lack of consensus and decision-making delays. This leads to the following hypothesis:

\section{H5: Directors with postgraduate qualifications are negatively correlated with profitability}

A summary of the theoretical themes regarding the role of the board used in the development of this study's hypotheses is illustrated in Figure 3 and discussed further under the respective variables selected for this study.

Table 3. Corporate governance theoretical framework

\begin{tabular}{|c|l|}
\hline \multicolumn{1}{|c|}{ Theory } & Role of Board \\
\hline Agency theory (1932) & •Monitor management \\
\hline Shareholders' theory (1962) & •Protector of shareholders \\
\hline Resource dependency theory (1972) & •Conduit to resources \\
\hline Stakeholders' theory (1984) & •Guardian to all stakeholders \\
\hline Stewardship theory (1990) & •Empower management \\
\hline Management hegemony theory (1998) & •Support to management \\
\hline
\end{tabular}

Source: Author

\section{Research methodology}

There are several advantages to using the GMM estimator as opposed to the customary OLS or fixed-effects estimator (Wintoki et al., 2012). This study employed GMM estimation for the panel data analysis due to the reverse causality issues between profitability and board attributes since firms choose their optimal level of corporate governance practices in response to internal firm characteristics, such as profitability. However, pooled OLS was used as a comparative model. Arellano and Bond (1991) and Arellano and Bover (1995) developed the dynamic panel GMM estimator which addresses the endogeneity concerns due to unobserved heterogeneity, simultaneity and reverse causality. However, the one-step GMM, first difference (FD-GMM) may be prone to weak instrument issues, due to the correlations between the differences and the levels of independent variables used as instruments for first differences being small. When there is a weak correlation issue, Arellano and Bover (1995) and Blundell and Bond (1998) recommended the two-step GMM, system GMM (SYS-GMM). The merits of dynamic GMM are that it allows current board attributes to be influenced by previous realisations of, or shocks to, past performance since GMM relies on its own internal instruments where past profitability can be used as instruments for current board attributes. In this context, fluctuations in profitability may influence changes in the board structure.

This study did not use fixed-effect estimation since it requires significant within-firm variation for the board variables to produce consistent and efficient results. For this reason, time-invariant board attributes cannot be estimated with fixed-effect regressions since the independent variables do not vary much over time, resulting in estimates that are not robust (Wooldridge, 2010). Furthermore, the suitability of GMM estimation is due to one of the strict conditions of SYS-GMM is that T should be small and $\mathrm{N}$ should be large and in this study the T (6 years) is small and the $\mathrm{N}$ (713) is large, which according to Baltagi (2008) will render fixed-effect estimation inconsistent. Also, fixed-effect estimation would lead to a large loss of degrees of freedom (Baltagi, 2008; Wooldridge, 2010). To alleviate survivorship bias, the sample includes companies that have undergone a non-random exit (such as suspension, delisting or liquidation) which also provided gaps in the panel dataset resulting in the employment of orthogonal deviations as an alternative to first differences to maximise the estimation of the sample. This study used the Stata/SE software program to calculate all of the estimations for this sample.

\section{Data sampling techniques}

Due to the divergent operating activities and accounting practices, a phased approach was applied to eliminate companies from basic materials, oil and gas and financial industries as well as secondary listings, listed on the Altx, venture capital market and traded securities from the sample. The final data set is an unbalanced set of 130 firms with 713 firm-year observations from 2011 to 2016. The selection of the period of analysis was critical to this study since 
it was a post-global financial crisis and therefore this period had exposure to the reforms of King III (King Committee, 2009) and the Companies Act No. 71 of 2008 (Parliament of the Republic of South Africa, 2009). All financial and governance information was extracted from the IRESS Research Domain.

\section{Model specification}

This study had three categories of variables, namely performance variable, governance variables, and control variables. Methodologically, the following empirical model was constructed:

Prof $_{i t}=\beta 0+\mu_{i}+\beta 1$ CEOdual $i t+\beta 2$ Binter $_{i t}+\beta 3$ Bsize $_{i t}+\beta 4$ Bind $_{i t}+\beta 5$ Dqual $_{i t}+C V_{i t}+\epsilon_{i t}$

where $i$ indicates a particular firm, $t$ (2011-2016) denotes the time in years, $\in_{i t}$ is a stochastic error term that represents the unobserved time-invariant firm effects.

\section{Measure of firm performance}

Firm profitability is measured by several approaches namely return on sales (ROS), ROE, and ROA (Yoo \& Kim, 2015). However, ROA has the benefit of assessing the efficiency and effectiveness of the management of assets to generate profits whereas ROE and ROS cannot capture the inclusive perspective of corporate profitability (Yoo \& Kim, 2015). On average, a higher ROA implies maximising shareholder value. Zabri et al. (2016) proved that ROA served as a better proxy for firm performance than ROE. Accordingly, the dependent variable, ROA (Prof ${ }_{i t}$ ) was selected as the proxy for profitability in this study and is calculated as the ratio of income before interest and tax over average total assets of the company (i) at year (t).

\section{Measure of the corporate governance structure}

The selection of the corporate governance variables was from the King report (Table 2), namely board size, board independence, CEO duality, director qualifications and board interlocks. The CEO-duality dummy (CEOdual) was set to be 1 for firms in which the CEO also plays a chairman role, and 0 otherwise. The Board interlocks (Binter)was set to 1 if there was greater than 50\% of the board members serving as CEOs or directors in other companies, otherwise 0 . The board-size variable (Bsize) was measured by the number of board directors. The independentdirector variable (Bind) was measured as 1 if the proportion of independent directors on the total number of directors was greater than $50 \%$, otherwise 0 . The director qualifications (Dqual) was set to 1 if majority (>80\%) of the directors had a professional qualification or postgraduate qualification, otherwise 0 . The conceptual model proposed for this study is presented in Figure 4 below. 


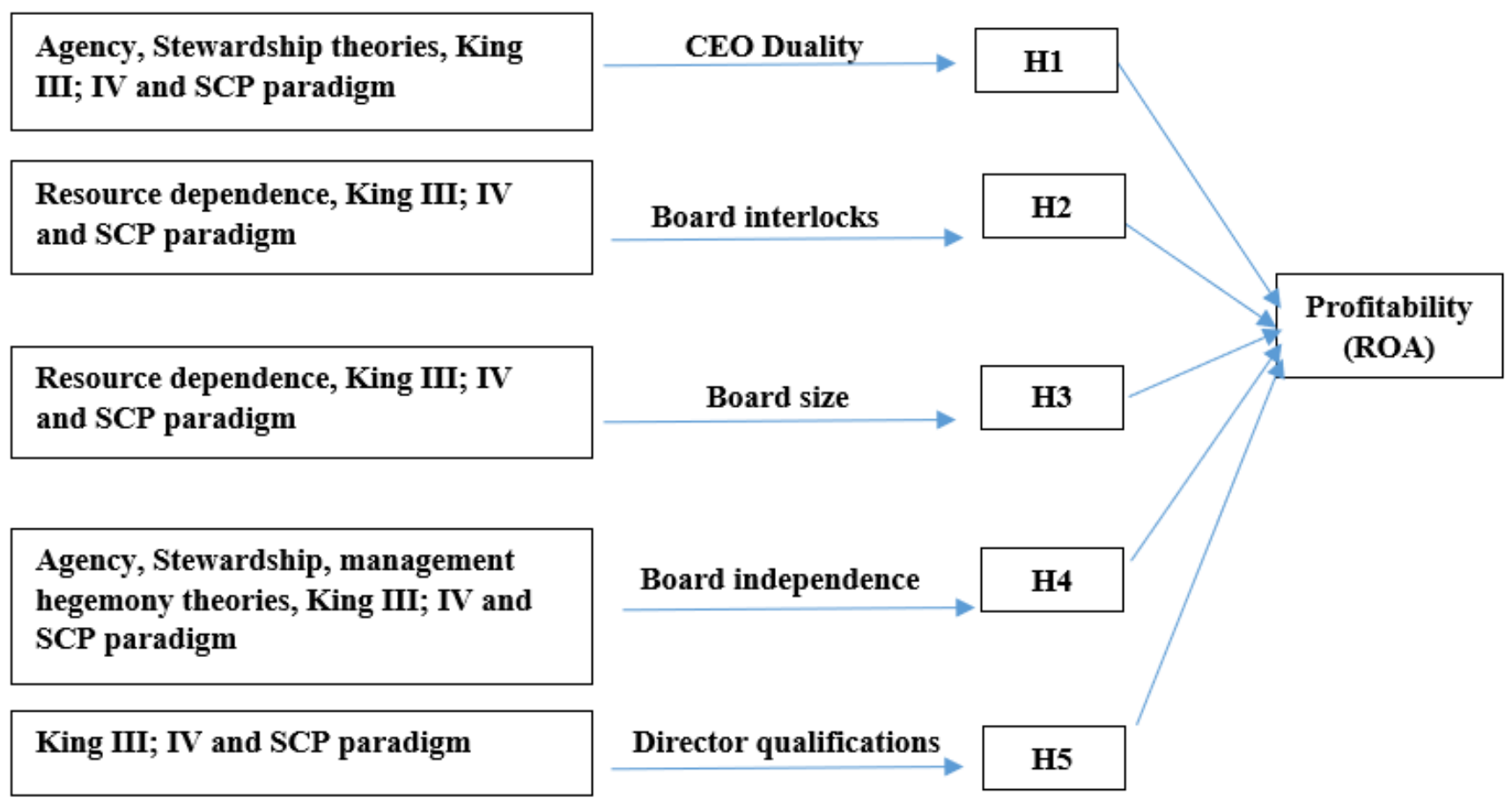

Figure 4. Conceptual model for this study

Source: Author

\section{Control variables}

Control variables(CVit) were incorporated into the model to isolate the effects of other factors that have a predictable influence on firm performance and to avoid any specification errors in the estimated model. To examine the impact of the board attributes on profitability, the firm's financial situation must be controlled by firm-specific variables, namely, firm size that was measured by the logarithm of the book value of total assets. The leverage variable was the ratio of the firm's total debt to its total assets as well as firm growth (Market to Book Value - Total Value). To control for any unobserved confounding factors at the sector level, this study's model specification included sectors, namely Consumer Goods, Consumer Services, Industrials, Health Care, Technology and Telecommunications.

\section{Results}

\section{Descriptive statistics and Pearson's correlation}

The correlation coefficients of the model variables are shown in Table 3, where the dependent, independent and control variables are statistically significant at a particular level as indicated by its p-values. In this context, the pairwise correlations do not present serious multicollinearity problems for the regression analyses since the highest correlation value is only 0.62 . The descriptive statistics in Table 3 show that ROA on average is $13.3 \%$ with a large standard deviation (13.90) thus making the median a better statistic where on average half of the firms had a ROA of $11.85 \%$. Table 3 also shows that leverage on average was $51.26 \%$ (median=51\%). There was a presence of CEO duality (3\%), which is specifically prohibited by King III and IV (King Committee, 2016) as well as by the agency theory. There are well-developed networks, since $90 \%$ of the boards have interlocking directors and on average, the board size comprises of 10 directors. A finding of $51 \%$ of the boards contravened the King III recommendation of having a majority of independent directors (>50\%) (King Committee, 2009). Only 52\% of the companies had boards with more than $80 \%$ of its directors with postgraduate degrees. The average firm size for companies in the sample was 6.5 , which was consistent with the median. The firm growth was on average 2.53 with a median of 1.61 . 
Table 3. Pearson's Correlation Matrix

N. S. Sewpersadh / ACRN Journal of Finance and Risk Perspectives 8 (2019) 133-151

\begin{tabular}{|c|c|c|c|c|c|c|c|c|c|c|c|c|c|}
\hline & ROA & $\begin{array}{l}\text { Sector } \\
\text { identity }\end{array}$ & Gearing & $\begin{array}{c}\text { CEO } \\
\text { duality }\end{array}$ & $\begin{array}{c}\text { Board } \\
\text { interlocks }\end{array}$ & $\begin{array}{l}\text { Board } \\
\text { size }\end{array}$ & $\begin{array}{c}\text { Board } \\
\text { independence }\end{array}$ & $\begin{array}{c}\text { Director } \\
\text { qualification }\end{array}$ & $\begin{array}{c}\text { Firm } \\
\text { size }\end{array}$ & $\begin{array}{c}\text { Firm } \\
\text { growth }\end{array}$ & & Std & \\
\hline & & & & & & & & & & & Mean & dev & Median \\
\hline \multirow[t]{2}{*}{ ROA } & 1 & & & & & & & & & & & & \\
\hline & & & & & & & & & & & 13.31 & 13.90 & 11.85 \\
\hline \multirow[t]{2}{*}{ Sector identity } & -0.04 & 1 & & & & & & & & & & & \\
\hline & & & & & & & & & & & $\mathrm{n} / \mathrm{a}$ & $\mathrm{n} / \mathrm{a}$ & $\mathrm{n} / \mathrm{a}$ \\
\hline \multirow[t]{2}{*}{ Gearing } & $-0.08 * *$ & $0.21 * * *$ & 1 & & & & & & & & & & \\
\hline & & & & & & & & & & & 51.27 & 22.04 & 51.00 \\
\hline \multirow[t]{2}{*}{ CEO duality } & 0.02 & $-0.07 *$ & -0.01 & 1 & & & & & & & & & \\
\hline & & & & & & & & & & & 0.03 & 0.17 & 0.00 \\
\hline \multirow[t]{2}{*}{ Board interlocks } & 0.02 & -0.03 & $0.16 * * *$ & 0.03 & 1 & & & & & & & & \\
\hline & & & & & & & & & & & 0.90 & 0.30 & 0.00 \\
\hline \multirow[t]{2}{*}{ Board size } & $0.09 * *$ & $-0.11 * * *$ & $0.12 * * *$ & $-0.08 * *$ & $0.18 * * *$ & 1 & & & & & & & \\
\hline & & & & & & & & & & & 9.94 & 2.88 & 10.00 \\
\hline \multirow[t]{2}{*}{ Board independence } & -0.03 & $-0.09 * *$ & $0.14 * * *$ & -0.04 & $0.14 * * *$ & $0.13 * * *$ & 1 & & & & & & \\
\hline & & & & & & & & & & & 0.51 & 0.50 & 1.00 \\
\hline \multirow[t]{2}{*}{ Director qualification } & 0.02 & 0.04 & $0.20 * * *$ & -0.01 & $0.25 * * *$ & $0.13 * * *$ & $0.29 * * *$ & 1 & & & & & \\
\hline & & & & & & & & & & & 0.52 & 0.50 & 1.00 \\
\hline \multirow[t]{2}{*}{ Firm size } & $0.06^{*}$ & -0.04 & $0.26 * * *$ & -0.06 & $0.20 * * *$ & $0.62 * * *$ & $0.32 * * *$ & $0.30 * * *$ & 1 & & & & \\
\hline & & & & & & & & & & & 6.52 & 0.74 & 6.49 \\
\hline \multirow[t]{2}{*}{ Firm growth } & $0.46 * * *$ & $-0.10 * * *$ & $0.13 * * *$ & 0.05 & $0.14 * * *$ & $0.27 * * *$ & $0.14 * * *$ & $0.13 * * *$ & $0.30 * * *$ & 1 & & & \\
\hline & & & & & & & & & & & 2.53 & 2.67 & 1.61 \\
\hline
\end{tabular}

$* * *, * *, *$ denote significance at $1 \%, 5 \%$ and $10 \%$ respectively

Source: Author 


\section{The econometric results}

The pooled OLS regression is presented in Table 4, where the R2 (0.24) suggests a non-linear relationship since $24 \%$ of the variation in profitability is determined by the linear relationship between profitability and board variables. Board attributes, being an endogenous result of an optimising process, could lead to less reliable estimates from a pooled OLS regression. Furthermore, the inclusion of delisted companies leads to missing observations and due to OLS not being robust, the orthogonality of the error term is violated. Thus, it is reasonable to conclude that outliers do influence the pooled regression results so that they may not reflect reality. In Table 4, it can be seen that gearing was negatively significant in the pooled OLS model within a $1 \%$ significance, indicating that as leverage increases, the profitability decreases.

The system GMM estimation presented in Table 4 is estimated on the dynamic panel which uses the lags of the variables that are endogenous as instruments. The number of observations (583) differs from the other models (713) since this is lag dependent. Prior research was inclined to employ either one lag or two lags to capture the dynamic relationship between governance structure and firm performance (Wintoki et al., 2012). However, it is vital to comprehend how many lags of dependent variables in the panel GMM model are required to capture all the information. Since too-long lags will lead to a loss of degrees of freedom and over-parameterisation, while too-short lags might create biased results caused by omitting key variables and failing to capture the variable's dynamics. For that reason, the lag length in this model was empirically determined. The GMM estimation with the use of external instruments is presented in Table 4. The use of instrument variables may weaken the Sargan/Hansen testing and can reduce the statistic (Roodman, 2009). In Table 4, it can be seen that in the FD-GMM, the results are the same as the dynamic panel SYS-GMM. Since FD-GMM is prone to weak instrument issues that could explain these results.

Due to the limitations in the models discussed above, this study specified the SYS-GMM with external instruments as shown in Table 4. In Table 4, firm growth was highly significant in all the models with a 5-10\% significance which indicates that firm growth is positively influenced by profitability. Firm size has a 5\% significance in SYSGMM and accordingly implies that profitability decreases with firm size. The sector identity was not significant. This study has estimated a robust model as seen by the high p-values of the Hansen J statistic (>0.25) in GMM models presented in Table 4, which indicates valid instruments (Roodman, 2009).

\section{H1: CEO duality is negatively correlated with profitability}

In Table 4, CEO duality is significantly negatively correlated with profitability. The result of $10 \%$ significance supports the hypothesis that CEO duality decreases profitability which is consistent with the findings by Kalsie and Mittal Shrivastav (2016) and Qadorah and Fadzil (2018). This finding is contrary to the finding of Habib (2016) and Scafarto et al. (2017) who found a positive correlation with ROA and Ciftci et al. (2019) who found an insignificant relationship.

\section{H2: Board interlocks are negatively correlated with profitability}

In Table 4, board interlocks are significantly negatively correlated with profitability. The $5 \%-10 \%$ significance provides evidence to support the hypothesis that an increase in interlocking directorates leads to decreases in profitability. This key finding is consistent with the King IV report recommended practice (P7RP18) as well as MansKemp et al. (2016) where it was recommended that directors should limit their board memberships to give sufficient attention to the activities of all firms which they serve. A case study by Vesco and Beuren (2016) found that the characteristics of the governing board and the practice of board interlocking in Eskom proved to be insignificant with the market value. On the contrary, Habib (2016) found a positive correlation with ROA. 
Table 4. Panel data analysis

Dependent variable: Profitability (Profit=ROA)

\begin{tabular}{|c|c|c|c|c|}
\hline & \multirow{2}{*}{$\begin{array}{c}\text { Pooled Ordinary } \\
\text { Least Square }\end{array}$} & \multirow{2}{*}{$\begin{array}{c}\text { Dynamic Panel } \\
\text { SYS-GMM }\end{array}$} & \multicolumn{2}{|c|}{ GMM with IV } \\
\hline & & & FD-GMM & SYS-GMM \\
\hline \multirow[t]{2}{*}{ CEO duality } & -1.068 & -5.764 & -30.86 & $-34.19 *$ \\
\hline & -2.484 & -20.07 & -21.31 & -20.28 \\
\hline \multirow[t]{2}{*}{ Board interlocks } & -0.705 & $-10.44 *$ & $-15.59 * *$ & $-10.33 * *$ \\
\hline & -1.253 & -6.323 & -7.691 & -4.491 \\
\hline \multirow[t]{2}{*}{ Board size } & 0.0629 & 1.064 & 1.433 & $1.125^{*}$ \\
\hline & -0.212 & -0.858 & -1.003 & -0.61 \\
\hline \multirow[t]{2}{*}{ Board independence } & $-2.044 * *$ & $-8.077 *$ & $-9.880 * *$ & $-4.514^{* *}$ \\
\hline & -0.983 & -4.328 & -3.867 & -2.169 \\
\hline \multirow[t]{2}{*}{ Director qualification } & 0.559 & 0.249 & -2.123 & $-3.305^{*}$ \\
\hline & -0.969 & -4.434 & -2.734 & -1.928 \\
\hline \multirow[t]{2}{*}{ Firm size } & -0.677 & -5.761 & -2.95 & $-7.005^{* *}$ \\
\hline & -1.019 & -4.46 & -3.728 & -3.304 \\
\hline \multirow[t]{2}{*}{ Firm growth } & $2.597 * * *$ & $2.868 * *$ & $4.440 * * *$ & $3.861 * * *$ \\
\hline & -0.53 & -1.297 & -0.966 & -0.767 \\
\hline \multirow[t]{2}{*}{ Sector identity } & 0.284 & -0.00428 & -0.202 & 0.34 \\
\hline & -0.386 & -3.302 & -0.88 & -0.797 \\
\hline \multirow[t]{2}{*}{ Gearing } & $-0.0867 * * *$ & 0.194 & 0.0546 & 0.0909 \\
\hline & -0.0314 & -0.166 & -0.118 & -0.0903 \\
\hline \multirow[t]{2}{*}{ Constant } & $15.85 * * *$ & $30.29 *$ & 23.95 & 19.29 \\
\hline & -5.406 & -18.05 & -19.23 & -16.87 \\
\hline Observations & 713 & 583 & 713 & 713 \\
\hline Number of IDs & 130 & 130 & 130 & 130 \\
\hline R-squared & 0.24 & $\mathrm{n} / \mathrm{a}$ & $\mathrm{n} / \mathrm{a}$ & $\mathrm{n} / \mathrm{a}$ \\
\hline Hansen & & 21.22 & 35.92 & 35.88 \\
\hline Hansen p-value & & 0.507 & 0.918 & 0.817 \\
\hline $\mathrm{AR}(2)$ & & 1.209 & 0.418 & 0.406 \\
\hline $\mathrm{AR}(2) \mathrm{p}$-value & & 0.227 & 0.676 & 0.685 \\
\hline
\end{tabular}

Note: Robust standard errors in parentheses. $* * *, * *, *$ denote significance at $1 \%, 5 \%$ and $10 \%$ respectively.

Source: Author

\section{H3: Board size is positively correlated with profitability}

As illustrated in Table 4, the results for board size shows a positive relationship with profitability $(\mathrm{p}<0.1)$. Thus, board size is significantly positively correlated with profitability where an increase in board size increases profitability. This result is supported by the recommended practice (P7RP7(c)) where it was emphasised that there needs to be a sufficient number of board members that qualify to serve on board committees (King Committee, 2016). This finding is also consistent with Scafarto et al. (2017) and Qadorah and Fadzil (2018) who also found a positive association between board size and ROA. On the contrary, Habib (2016) found a negative correlation with ROA thus 
surmising that an increase in board size decreases profitability. However, Zabri et al. (2016) found that board size is insignificant with ROE and had a weak relationship with ROA.

\section{H4: Board independence is negatively correlated with profitability}

In Table 4, board independence is significantly negatively correlated with profitability. The $5 \%-10 \%$ significance provides evidence to support the hypothesis suggesting that an increase of independent directors on the governing board leads to a decrease in profitability. The finding is supported by Ciftci et al. (2019), Scafarto et al. (2017) and Bhabra and Eissa, (2017) who also found that a large number of independent directors negatively affected firm performance. On the contrary, Zabri et al. (2016) did not find any association between board independence and firm performance.

However, this result does not support the King IV recommendation that there should be a majority of independent directors.

\section{H5: Directors with postgraduate qualifications are negatively correlated with profitability}

In Table 4, board members with postgraduate degrees are negatively correlated with profitability $(\mathrm{p}<0.1)$. This study's findings are supported by Bhabra and Eissa (2017) where it was found that boards with directors where the number of educational achievements varies significantly, could lead to greater difficulties in reaching a consensus on strategic corporate policies which ultimately negatively impacts profitability. The varied opinions of these directors lead to lengthy delays in arriving at a strategic decision, which could prove to be costly in the long-term, especially for firms experiencing a decline in profitability (Bhabra \& Eissa, 2017). This study's result is consistent with management hegemony theory where, although directors may be suitably qualified but the limitations of information asymmetry and time constraints could lead to them not being as vested in the firm as executive management. However, King IV (P7RP6) recommends that the board members should have a balance of knowledge, skills, experience and diversity, but there is no specific guidance on what type of knowledge and skills are endorsed. A summary of the hypotheses supported, together with the relevant theory leading the foundation, is presented in Table 5.

Table 5. Results of the hypothesis testing

\begin{tabular}{llll}
\hline Hypotheses & Theory & \multicolumn{1}{l}{ Results } \\
\hline H1 & CEO duality is negatively correlated with profitability & Agency theory; King IV & Supported \\
H2 & Board interlocks are negatively correlated with profitability & King IV & Supported \\
H3 & Board size is positively correlated with profitability & King IV; resource Supported \\
& & dependence model & Supported \\
H4 & Board independence is negatively correlated with profitability & Management hegemony & theory \\
& & & Management hegemony \\
H5 & Directors with postgraduate qualifications are negatively & Surted \\
& correlated with profitability & theory & \\
\hline
\end{tabular}

Source: Author 


\section{Discussion}

\section{CEO Duality}

This study has found that CEO duality decreases profitability due to managerial opportunism that compromises the governing board's oversight role which ultimately leads to a CEO dominated board. The presence of CEO duality does not bode well for the company due to the following factors of a CEO dominated board:

- The same person sets the agenda for the board as well as controls the issues brought to and addressed by the board. - Nomination and appointment of board members are compromised which ultimately results in a lack of independence of the board.

- The inadequate interrogation of the firm's poor performance since it could be linked to the inefficient decision making of the CEO.

The finding of this study is aligned with the agency theory which outlines the risks of CEO duality specifically managerial opportunism. Furthermore, agency theory and King III states that the monitoring of management is less effective if the role of CEO and chairperson of the board is fulfilled by the same person (Sewpersadh, 2019). For this reason, King IV (P7RP31) specifically prohibits the CEO serving as a chairperson since it has to be fulfilled by an independent non-executive director (King Committee, 2016).

\section{Board interlocks}

This study has found that board interlocks lead to decreases in profitability. This is due to the directors serving on too many company boards, which negatively affects their fiduciary duties towards these companies as well as risks the sharing of these companies competitive and strategic advantages. Directors serving on each other's boards are unlikely to rigorously criticise their peers and, should they have the inclination, the lack of time and information symmetry prevents the directors from a serious review of company managers. Mans-Kemp, Erasmus and Viviers (2016) termed the inability of heavily interlocking directors to conduct their board duties with sufficient care and due diligence, as 'over-boarded directors'. Specific guidance was provided in King IV concerning board members serving on many other boards that may not have sufficient time available to fulfil their responsibilities as directors. There are benefits from interlocking directors being an effective mechanism for the firm gaining external contacts or links with the environment as proposed by the resource dependence model. However, this study highlights the risks of interlocking directorates to the profitability and sustainability of the firms where directors serve on too many boards.

\section{Board size}

This study found that increases in board size lead to increases in profitability. This is mainly due to the size of the board being influenced by the firm's requirements for co-opting key external elements from its environment. Accordingly, the size of the board is viewed as a crucial indicator for its effectiveness in reducing agency costs stemming from inefficient management of the firm, hence enhancing firm performance. The advantages of increasing board sizes with the profitability of the firm finds credence in the resource dependence model, which suggests that large boards offer firms numerous benefits in achieving its strategic objectives by gaining access to the resources and information held by the board members (Pfeffer, 1972). However, Sewpersadh (2019) cautions that "the board should be large enough to perform efficiently, yet not so large that the board has difficulties in maintaining the balance of interests leading to the detriment of the company". For board size in SA, there is a minimum of three directors but no maximum directorships are stipulated (OECD, 2017). This study concurs with the results found in Sewpersadh (2019) that the minimum of 3 directors signifies inefficiency on the boards in SA and therefore should be revised.

\section{Board independence}

This study found that an increase in independent directors leads to a decrease in profitability due to the independent directors being so far removed from the day-to-day operations, together with information asymmetry, which impairs their strategic growth-oriented vision. The management hegemony theory further proposed that independent directors may have compromised incentives which impairs their decision-making skills. Although there are merits to having independent directors due to their oversight role in controlling managerial opportunism as highlighted in the agency theory. However, there are risks that many firms may appoint independent directors on the board as a display of 
compliance resulting in the board playing an insignificant role in monitoring management. These directors may appear independent but in actuality, may not be truly independent since these directors may be related parties to the management of the firms. Achieving board independence may prove difficult to achieve due to the risks of compromised incentives and/or related parties with management. For this reason, the King report requires the independence of the independent director be assessed annually (King Committee, 2009;2016). Furthermore, the stewardship theory encourages independent directors to work jointly with management in developing strategies and monitoring performance which has the advantages of shared vision and drive but may also carry the risks of compromised board independence.

\section{Director qualifications}

This study found that boards that have an increasing number of directors with post-graduate qualifications leads to decreases in profitability. Irrespective of post-graduate qualifications, directors may not be as vested in the financial health of the firm as executive management, thus leading to poor growth and profitability strategies. Furthermore, due to the perceived insight and overconfidence that directors with post-graduate qualifications may have, may lead to increases in conflicts resulting in compromises and delays in the decision-making process. Management hegemony theory highlighted that information asymmetry and time constraints prevail regardless of how qualified the directors are, thus there is a negative association to profitability (Hung, 1998). King IV (P7RP6) recommends that the board members should have a balance of knowledge, skills, experience and diversity however there is no specific guidance on what type of knowledge and skills are endorsed. The oversight of the King report in providing guidance regarding knowledge or endorsement of specific skills leads to the management of firms appointing directors with qualifications as a display of compliance, however failing to interrogate the benefit of their qualifications to their firms and thus creating a mismatch with the company's operational environment.

\section{Conclusion}

SA was ranked number one in the world in auditing and reporting standards in the World Economic Forum's Global Competitiveness Report 2016/17 for the seventh consecutive year (Grant Thornton, 2016). However, the unabating corporate scandals in SA emphasises the need for pro-active actions rather than post-mortem exercises as presently examined in this study. This study provides significant contributions to SA's ailing economic market by innovatively investigating alternative profitability indicators, which may provide new avenues for regulators, corporate management and governing bodies to build corporate strategies in organisations.

From a research methodology perspective, this study provided a unique perspective in examining the endogeneity that usually plagues corporate governance studies by using the versatility of GMM estimation and including lags and instrument variables to interrogate the model variables. Furthermore, the robustness of using GMM estimation to address the potential endogeneity problems that may have influenced the results of existing international and domestic studies that used other econometric models. The findings in this study suggest that, after controlling for all sources of possible endogeneity, there are significant associations between the governing board characteristics and profitability. The robustness of the study is also demonstrated by all the hypotheses being supported and evidenced by theory or prior research, with some results refuting other studies' findings.

From a theoretical perspective, this study has provided an examination of the various theories about board attributes. The managerial hegemony theory proposes that the main role of the governing board is to support the decisions made by executive management (Mace, 1971). Hung (1998) stated that directors have incentives such as reappointments to the board, and the accumulated benefits thereof, to entice their compliance with management. The directors' independence is also compromised due to their reliance on information supplied by management (information asymmetry) or the directors' lack of essential skills to make effective decisions (Hung, 1998). To the extent that information remains asymmetrical, monitoring by governing boards remains ineffective. Therefore, as posited by the resource dependence model, an internal focus on the firm's resources can reduce information asymmetry and will emphasise the fiduciary role of directors in providing various kinds of advice to management. The shareholder theory posits that management has a primary duty of shareholder wealth maximisation (Berle \& Means, 1932; Friedman, 1962). However, a "share-centred view" tends to focus on short-term profitability (Greenwood, 2004), which is a limitation of the shareholder theory since it usually deters other key sustainable strategies from achieving business success (Clarke, 2014). Consequentially, a strategy focused on short-term profitability is less resilient during periods of long-term stagnation that trigger corporate management to select "de- 
growth" by reducing its scale of operations (Yoo \& Kim, 2015). In this context, the board plays a key role in ensuring that management's strategies are directed towards value maximisation and not value extraction for the self-interests of management.

From an econometric perspective, the results as envisaged in the SCP paradigm, board structure influences the conduct variables of board size, board independence, CEO-chairperson duality, director qualifications and board interlocks which in turn influence profitability with the feedback effect of profitability on the board conduct variables and structure. This study also found that the size of the board has a positive correlation with profitability. As highlighted in the resource dependence model and King IV, the size of the board should be sufficient to carry out all the duties of the committees that they serve. However, there is an inverse relationship with profitability and the following board attributes: the presence of CEO duality, board interlocks, board independence and director qualifications. As proposed by the agency theory and King IV that CEO duality had the risks of managerial opportunism, greater information asymmetry and ultimately a CEO dominated board. Whereas, the resource dependence model proposed the interlocking of boards for access to resources and information that would not be otherwise available. However the limitation to this model, as highlighted in the King IV report and the theory of 'overboardedness' (Mans-Kemp, Erasmus, \& Viviers, 2016), is that the directors serving on multiple boards would not have sufficient time to adequately fulfil their director duties which could be detrimental to the company. Furthermore, this study highlights the following risks to highly interlocking directors:

- Directors will not have the aptitude due to information asymmetry to assimilate their strategies and apply their minds adequately to a particular company circumstances and market deposition.

- Scheduling conflicts will result in the directors' absenteeism which could result in the director missing key information presented at the board meetings.

- The disclosure of company strategies or confidential information to other companies could result in the company losing its competitive edge.

Contrary to the King IV report recommending the majority of independent non-executive directors, the management hegemony theory proposed that for strategic direction these directors are not involved in the operations of the firm and therefore do not have the aptitude to drive strategy. Accordingly, this relates to the finding of the director qualifications' negative correlation with profitability since, irrespective of educational qualifications, there are still the same limitations as outlined for board independence. This study highlighted the key limitation of the independent non-executive directors that do not have sufficient time and adequacy of operational and market positioning knowledge to effectively drive strategy in light of the restrictions of information asymmetry and disengagement of the operational duties of the company. This key limitation affects the variables of board independence, highly qualified board members and board interlocks.

\section{Recommendations}

Since governing boards are a strategic resource as well as an oversight body, King IV has placed emphasis on trust in the governing boards. This study provided evidence of the important constructs of governing boards and their association with profitability. In this context, this study recommends the following:

- The King report should provide recommendations on which professional and academic qualifications that are most beneficial to boards. There should also be specific guidance on the assessment of the knowledge, skills and expertise that directors need to have.

- The King report should also provide guidance on board size which should increase with the firm's size, growth and requirement for resources.

- The King report together with the Companies Act (2008) should stipulate the maximum number of boards that directors may serve on. There should be also be penalties attached to companies and directors that breach the maximum.

- A study should be conducted on the monopoly of certain directors that are currently serving on multiple boards.

- Research should be conducted on the stakeholder hierarchy which boards apply when balancing the interests of various stakeholders.

- Board appointments made due to political affiliations should be examined.

- Research on companies' assessments of board independence should be conducted. 


\section{Limitations}

This study was conducted in a market with a formalised corporate governance structure and therefore the findings may not apply to countries with corporate governance in its infancy.

\section{Acknowledgments}

The author expresses gratitude to the two anonymous reviewers for their time and effort in refining and improving this article.

\section{Competing interests}

This is a declaration to confirm that the views expressed in this article are those of the author and there is no conflict of interests that may have inappropriately influenced the writing of this article.

\section{Ethical statement}

The ethical clearance for this paper has been obtained from the UKZN research office as part of a larger study "An investigation into financial distress and corporate governance in JSE listed companies" (clearance no: HSS/0703/017M) from which the data for this article has been obtained.

\section{References}

Aldrich, H. E., \& Pfeffer, J. (1976). Environments of Organizations. Annual Review of Sociology, 2, 79-105.

Arellano, M., \& Bond, S. (1991). Some tests of specification for panel data: Monte Carlo evidence and an application to employment equations. The review of economic studies, 58(2), 277-297.

Arellano, M., \& Bover, O. (1995). Another look at the instrumental variable estimation of error-components models. Journal of Econometrics, 68(1), 29-51.

Baltagi, B. (2008). Econometric analysis of panel data (4th ed.). Chichester: John Wiley and Sons.

Berle, A., \& Means, G. (1932). The modern corporation and private property. New York: Macmillan.

Bhabra, H. S., \& Eissa, A. H. (2017). Corporate Financial Distress and CEO Networks. Montreal: Concordia University.

Blundell, R., \& Bond, S. (1998). Initial conditions and moment restrictions in dynamic panel data models. Journal of econometrics, 87(1), 115-143.

Boyd, B. K. (1995). CEO duality and firm performance: A contingency model. Strategic Management Journal, 16(4), $301-312$.

Ciftci, I., CTatoglu, E., Wood, G., Demirbag, M., \& Zaim, S. (2019). Corporate governance and firm performance in emerging markets: Evidence from Turkey. International Business Review, 28(1), 90-103.

Clarke, T. (2014). The impact of financialisation on international corporate governance: the role of agency theory and maximising shareholder value. Law and Financial Markets Review, 8(1), 39-51.

Cornforth, C. (2001). Understanding the governance of non-profit organizations: multiple perspectives and paradoxes. Miami: 30th Annual ARNOVA Conference, 29 November - 1 December 2001.

Dalton, C. M., \& Dalton, D. R. (2005). Boards of directors: Utilizing empirical evidence in developing practical prescriptions. British Journal of management, 16, 91-97.

Dalton, D. R., \& Daily, C. M. (1999). What's Wrong With Having Friends On the Board? Across the Board, 36(3), $28-32$.

Davis, J. H., Schoorman, F. D., \& Donaldson, L. (1997). Toward a stewardship theory of management. Academy of Management Review, 22(1), 20-47.

Donaldson, L., \& Davis, J. H. (1991). Stewardship Theory or Agency Theory: CEO Governance and Shareholder Returns. Australian Journal of Management, 16(1), 49-65.

Fama, E. F., \& Jensen, M. C. (1983). Separation of Ownership and Control. Journal of Law and Economics, $26(2), 301-325$.

Freeman, E. R. (1984). Strategic management: a stakeholder approach. Boston. Boston: Pitman.

Friedman, M. S. (1962). Capitalism and Freedom (1 ed., Vol. 1). Chicago: University of Chicago Press.

Parliament of the Republic of South Africa. (2009). Companies Act No. 71 of 2008 . Cape Town: Government Gazette.

Parliament of the Republic of South Africa. (2015). Protection of Investment Act No. 22 of 2015. Cape Town: Government Gazette .

Grant Thornton. (2016). SA needs steady flow of registered auditors to maintain global Number One position for Auditing and Reporting Standards. Retrieved July 26, 2018, from https://www.grantthornton.co.za/Newsroom/sa-needs-steady-flow-ofregistered-auditors-to-maintain-global-number-one-position-for-auditing-and-reporting-standards/

Greenwood, D. J. (2004). Enronitis: Why good corporations go bad. Columbia Business Law Review, 773-848. 
Habib, M. (2016). Relationship Between Corporate Governance and Firm Performance: A Case Study In Bangladesh. International Scholar Journal of Accounting and Finance, 2(1), 11-20.

Head, T. (2018). The South African. Retrieved September 15, 2018, from https://www.thesouthafrican.com/gdp-recessionpredictions-south-africa-why/

Hung, H. (1998). A typology of the theories of the roles of governing boards. Corporate Governance An International Review • February 1998, 6(2), 101-111.

Jensen, M. C. (1986). Agency costs of free cash flow, corporate finance, and takeovers. The American economic review, 76(2), 323-329.

Jensen, M. C. (1993). The Modern Industrial Revolution, Exit, and Control Systems. The Journal of Finance, 48(3), 831-880.

Jensen, M. C. (2001). Value maximization, stakeholder theory, and the corporate objective function. Journal of Applied Corporate Finance, 14(3), 8-21.

Jensen, M. C., \& Meckling, W. H. (1976). Theory of the firm: Managerial behavior, agency costs and ownership structure. Journal of financial economics, 3(4), 305-360.

Kalsie, A., \& Mittal Shrivastav, S. (2016). The Relationship between CEO Duality and Firm Performance: An Analysis Using Panel Data Approach. The IUP Journal of Corporate Governance, XV(2), 37-58.

King Committee. (2009). King Code of governance principles for South Africa. Johannesburg: Institute of Directors.

King Committee. (2016). King IV Report on Corporate Governance for South Africa. Johannesburg: Institute of Directors.

Kor, Y. Y., \& Sundaramurthy, C. (2009). Experience-based human capital and social capital of outside directors. Journal of management, 35(4), 981-1006.

Lakshan, A., \& Wijekoon, W. (2012). Corporate governance and corporate failure. Procedia Economics and Finance, 2 , 191 198.

Li, H.-X., Wang, Z.-j., \& Deng, X.-1. (2008). Ownership, independent directors, agency costs and financial distress: Evidence from Chinese listed companies. Corporate Governance: The international journal of business in society, 8(5), 622-636.

Li, J., \& Yu, L. (2016). Double externalities, market structure and performance: an empirical study of Chinese unrenewable resource industries. Journal of Cleaner Production, 126, 299-307.

Mace, M. L. (1971). Directors: Myth and Reality. Boston: Harvard University Press.

Mans-Kemp, N., Erasmus, P., \& Viviers, S. (2016). Measuring corporate governance in South Africa: Developments, concerns and suggestions. Southern African Journal of Accountability and Auditing Research, 18(1), 93-104.

Melé, D., Rosanas, J. M., \& Fontrodo, J. (2017). Ethics in finance and accounting: Editorial introduction. Journal of Business Ethics, 140(4), 609-613.

Molyneux, P., \& Forbes, W. (1995). Market structure and performance in European banking. Applied Economics, 27(2), 155159.

Moya, S. (2018). Trading economics. Retrieved September 28, 2018, from https://radingeconomics.com/southafrica/unemployment-rate

OECD. (2017). OECD Corporate Governance Factbook 2017. Retrieved July 6, 2018, from http://www.oecd.org/daf/ca/Corporate-Governance-Factbook.pdf

Paniagua, J., Rivelles, R., \& Sapena, J. (2018). Corporate governance and financial performance: The role of ownership and board structure. Journal of Business Research, 89, 229-234.

Petchsakulwong, P., \& Jansakul, N. (2018). Board of directors and profitability ratio of Thai non-life insurers. Kasetsart Journal of Social Sciences, 39(1), 122-128.

Pfeffer, J. (1972). Size and Composition of Corporate Boards of Directors: The Organization and its Environment. Administrative Science Quarterly, 17(2), 218-228.

Pfeffer, J. (1987). A resource dependence perspective on intercorporate relations. Intercorporate relations: The structural analysis of business, 25-55.

Pfeffer, J., \& Salancik, G. R. (1978). The external control of organizations: A resource dependence perspective. New York: Harper \& Row.

Qadorah, A., \& Fadzil, F. (2018). The Relationship Between Board Size and CEO Duality and Firm Performance: Evidence from Jordan. International Journal of Accounting, Finance and Risk Management, 3(3), 16-20.

Roodman, D. (2009). How to do xtabond2: An introduction to difference and system GMM in Stata. The Stata Journal, 9(1), 86136.

Scafarto, V., Ricci, F., Corte, G. D., \& De Luca, P. (2017). Board structure, ownership concentration and corporate performance: Italian evidence. Corporate Ownership \& Control, 15(1), 347-359.

Sewpersadh, N.S. (2019). A theoretical and econometric evaluation of corporate governance and capital structure in JSE-listed companies. Corporate Governance: The international journal of business in society, 19(5), 1063-1081.

Shao, L. (2019). Dynamic study of corporate governance structure and firm performance in China. Chinese Management Studies, 13(2), 299-317.

Soltani, B. (2014). The anatomy of corporate fraud: A comparative analysis of high profile American and European corporate scandals. Journal of business ethics, 120(2), 251-274.

Vesco, D. G., \& Beuren, I. M. (2016). Do the Board of Directors Composition and the Board Interlocking Influence on Performance? Brazilian Administration Review, 13(2), 1-26. 
Wintoki, B. M., Linck, J. S., \& Netter, J. M. (2012). Endogeneity and the dynamics of internal corporate governance. Journal of Financial Economics, 105(3), 581-606.

Wooldridge, J. M. (2010). Econometric analysis of cross section and panel data. Cambridge: MIT press.

Yoo, S., \& Kim, J. (2015). The Dynamic Relationship between Growth and Profitability under Long-Term Recession: The Case of Korean Construction Companies. Sustainability, 7(12), 15982-15998.

Zabri, S. M., Ahmad, K., \& Wah, K. K. (2016). Corporate Governance Practices and Firm Performance: Evidence from Top 100 Public Listed Companies in Malaysia. Procedia Economics and Finance, 35, 287-296.

(c) (1) ()

(C) 2019 by the authors. Licensee ACRN Publishing, Austria, Editor in Chief Prof. Dr. Othmar M. Lehner. This article is an open access article distributed under the terms and conditions of the Creative Commons Attribution (CC BY SA) license (https://creativecommons.org/licenses/by-sa/4.0/) 